\title{
ALX4 Gene
}

National Cancer Institute

\section{Source}

National Cancer Institute. ALX4 Gene. NCI Thesaurus. Code C74965.

This gene is involved in both skull and limb development and transcriptional regulation. 